\title{
Yield, Water Use and Economics of Tuberose as Influenced by Different Irrigation Scheduling in Indo-Gangetic Plains
}

\author{
M. Banik ${ }^{1 *}$, P. Ghatak ${ }^{1}$, R. Ray $^{2}$ and S.K. Patra ${ }^{1}$ \\ ${ }^{1}$ Department of Agricultural Chemistry and Soil Science, Bidhan Chandra Krishi \\ Viswavidyalaya, Mohanpur- 741 252, West Bengal, India \\ ${ }^{2}$ Department of Soil and Water Conservation, Bidhan Chandra Krishi Viswavidyalaya, \\ Mohanpur- 741 252, West Bengal, India \\ *Corresponding author
}

A B S T R A C T

Optimum schedule of irrigation in limited water resources is a vital issue for sustainable production of ornamental plants. A field investigation was conducted during 2012-2013 at

\section{Keywords}

Polianthes tuberose, Irrigation schedule, Spike yield, Water use, Economic return

Article Info

Accepted:

07 March 2018

Available Online:

10 April 2018 the experimental field of Bidhan Chandra Krishi Viswavidyalaya, West Bengal, India to study the effect of three irrigation schedule viz., IW/CPE 0.4, IW/CPE 0.8 and IW/CPE 1.0 and three varieties viz., Prajwal, Calcutta single and Calcutta double on yield, water use and economics of tuberose. The experiment was laid out in a factorial randomized block design with three replications. The results of the study showed that higher irrigation schedule at IW/CPE 1.0 significantly increased the spike and bulb yields of plant, being comparative with moderate deficit irrigation schedule at IW/CPE 0.8. The performance of Calcutta double was better than Calcutta single and Prajwal in increasing yield at all irrigation levels, the more so in higher irrigation schedule than in lower deficit irrigation schedule. However, in view of moderate water use, higher yield and maximum economic returns, moderate deficit irrigation scheduling of IW/CPE 0.8 for Calcutta double or Calcutta single may be advocated for tuberose cultivators in Indo-Gangetic plains of West Bengal.

\section{Introduction}

Tuberose (Polianthes tuberose Linn.) also known as Rajnigandha is one of the most popular ornamental plants grown in India for its aesthetic social and commercial values. This herbaceous perennial bulbous plant produces attractive, elegant and delightful fragrant white flowers having excellent keeping quality (Patel et al., 2006). It is commercially grown as cut flower, loose flower as well as for its potential in perfumery industry (Padaganur et al., 2005; Alan et al., 2007). The flowers are used in wedding ceremonies, garlands, bowl and vase decoration and various traditional rituals. It has great demand in the domestic and international flower market and its production is highly profitable. In India, major tuberose cultivating states are Karnataka, Maharastra, Assam, Rajasthan, Gujarat, Tamil Nadu, Andhra Pradesh and West Bengal. There are 
many factors which adversely affect the growth, marketable yield and quality of flowers. Flower yield can be increased substantially with judicious amounts of nutrients and water application. Nitrogen, phosphorus and potassium are particularly important nutrients for maximizing flower quality and quantity characteristics. Tuberose is a gross feeder plant requiring a large quantity of NPK as inorganic and organic forms for optimum growth and higher flower and bulb production (Kabir et al., 2011). The balanced supply of NPK @ 30:30:20 g/m² respectively improved flower and spike production (Kour and Sharma, 2012). Optimum irrigation schedule and quantity of water applied are the deciding factors on increased yield and quality of flowers (ELNaggar and Byari, 2009; Deshmukh, 2012). The excessive or inadequate irrigation, on the other hand, has deleterious effects on plant growth, yield components and productivity (Halepyati et al., 1996). These findings thereby indicate that the most important cause of the lower crop and water productivity and nutrient use efficiency was farmers' inadequate technical knowledge about irrigation and plant nutrient planning and improper crop management practices.

Water is a vital natural resource for all agricultural crops including horticultural and ornamental crops. Its availability is decreasing day by day due to the over rising population growth, rapid urbanization and industrialization, and economic development. At present, as a result of global warming and competitive increasing demand for water from domestic and industry sectors, curtailment of allocation of water in irrigated agriculture is gradually diminishing. Water is going to be a scarce commodity in near future. This aggravated problem can be meted out to maximize the use of this limited water resource through optimum water management techniques. Under scarce condition, irrigation scheduling is considered as a vital component to produce higher water use efficiency under any irrigation system (Panigrahi et al., 2011). The meteorological based irrigation scheduling approach such as pan evaporation replenishment, cumulative pan evaporation, ratio between irrigation water and cumulative pan evaporation (IW/CPE) and soil moisture depletion have been used widely at the farmer's level.

In the Indo-Gangetic plains of West Bengal, tuberose occupies the leading position in respect of area and production (Biswas et al., 2002). The farmers commonly follow the furrow method of irrigation and conventional soil fertilization for its cultivation. Improper irrigation scheduling under furrow method creates a substantial loss of water and nutrients in fields, resulting in low flower yield and quality, and sub-optimum water and nutrient use efficiency. The problem becomes more acute in sandy loam soils, where deep percolation of water and nutrients is very high. Plant also suffers from water scarcity from March to June due to erratic distribution of rainfall. Since tuberose cultivation in this region is gaining popularity, it is necessary to find out optimum irrigation schedule to ensure maximum flower production and monetary benefit.

\section{Materials and Methods}

\section{Experimental site and soil characteristics}

A field investigation was conducted during the growing season of 2012-2013 at the Departmental Experimental Field of Bidhan Chandra Krishi Viswavidyalaya, Mohanpur, Nadia representing the Indo-Gangetic alluvial plains of West Bengal. The experimental site is located between $22^{\circ} 56^{\prime} \mathrm{N}$ latitude and $88^{\circ} 32^{\prime}$ E longitude with an average altitude of $9.75 \mathrm{~m}$ above mean sea level. The climate is sub-humid tropical. The average monthly 
maximum and minimum temperature experienced during the growing period ranged between $29.2^{\circ} \mathrm{C}$ and $35.6^{\circ} \mathrm{C}$ and $8.9^{\circ} \mathrm{C}$ and $26.2^{\circ} \mathrm{C}$, respectively. The relative humidity varied between $93.7 \%$ and $97.9 \%$. The wind speed was in the range of 0.2 to $0.7 \mathrm{kmph}$. There was 2.7 to 9.2 bright sunshine hours per day. The potential evapotranspiration during plant growth period was $1024 \mathrm{~mm}$ per year. The average annual rainfall was $1319 \mathrm{~mm}$ of which $75-80 \%$ being received during June through September. The soil is Gangetic alluvium (Typic fluvaquept) with sandy loam in texture. The soil is porous with good drainage facility. The soil is illite vdominant with appreciable amounts of chlorite, mixed layer minerals and kaolinite. The relevant physical, hydro-physical and chemical properties of the experimental are furnished in Table 1 and 2, respectively.

\section{Experimental treatments and design}

The field trial was consisted of nine treatment combinations with three irrigation schedules based on irrigation water (IW) to cumulative pan evaporation (CPE) ratio viz., IW/CPE 0.4, IW/CPE 0.8 and IW/CPE 1.0 and three varieties of tuberose viz., Prajwal, Calcutta single and Calcutta double. The experiment was laid out in factorial randomized block design with three replications.

\section{Agronomic manipulations}

The bulbs of three tuberose cultivars with uniform size (2.5-3.0 cm diameter and 15.5$17.7 \mathrm{~g}$ weight) were planted on 9 March 2012 at $5 \mathrm{~cm}$ depth with plant geometry of $30 \mathrm{~cm} \times$ $30 \mathrm{~cm}$ row to row and plant to pant distance. The unit plot size was $1.2 \mathrm{~m} \times 1.0 \mathrm{~m}$ leaving $0.5 \mathrm{~m}$ bund width and $1.0 \mathrm{~m}$ irrigation channel. The number of bulb planted per plot was 12. The bulbs prior to planting were treated with $0.2 \%$ Carbendazim for 30 minutes. Well decomposed farm yard manure
(FYM) containing $0.5 \% \quad \mathrm{~N}, 0.3 \% \quad \mathrm{P}_{2} \mathrm{O}_{5}$ and $0.5 \% \mathrm{~K}_{2} \mathrm{O}$ on dry weight basis @ $15 \mathrm{t} / \mathrm{ha}$ was applied at the time of final land preparation. The recommended doses of 200:200:150 $\mathrm{kg} / \mathrm{ha}$ of $\mathrm{N}, \mathrm{P}_{2} \mathrm{O}_{5}$ and $\mathrm{K}_{2} \mathrm{O}$ were applied as urea, single superphosphate and muriate of potash, respectively. Full $\mathrm{P}$ and $\mathrm{K}$ and onethird of $\mathrm{N}$ were applied as basal and remaining $\mathrm{N}$ was top-dressed in three splits at 25, 50 and 75 days after planting. Standard cultural practices were followed uniformly. Five representative plants from the inner rows of each replicated plot were labeled, tagged and used for recording of spike and bulb yield. Final harvesting of plant was completed in the third week of February 2013.

\section{Soil moisture distribution}

For soil moisture studies, samples were drawn at $0-15,15-30$ and $30-45 \mathrm{~cm}$ soil depth with the help of screw auger from central point of unit plot area of each treatment just before irrigation and 48 hours after irrigation and also at sowing and harvest of plant. The soil moisture content from each replication for respective treatment was determined by soil moisture probe. The data obtained for different irrigation schedules were used for calculating the soil moisture distribution down the layers of the soil profile.

\section{Estimation of crop water use}

Crop water use during the growing period (planting to harvest) from the tuberose crop field was computed using the one-dimensional water balance equation (Simsek et al., 2005) as follows,

$\mathrm{WU}=\mathrm{P}+\mathrm{I}+\mathrm{Cp}-\mathrm{Dp}-\mathrm{Rf} \pm \Delta \mathrm{S}$

Where, WU is the crop water use $(\mathrm{mm}), \mathrm{P}$ is the precipitation, $\mathrm{Cp}$ is the contribution through capillary rise from groundwater, Dp is the deep percolation, $\mathrm{Rf}$ is the surface runoff 
and $\pm \Delta \mathrm{S}$ is the change in soil water storage in the profile between planting and harvest time $(\mathrm{mm})$. Since the groundwater was very deep ( 5 to $6 \mathrm{~m}), \mathrm{Cp}$ was assumed to be negligible. There was no Rf because of low depth of water application and occurrence of low intensity of rainfall.

So, $\mathrm{WU}=\mathrm{P}+\mathrm{I}-\mathrm{Dp} \pm \Delta \mathrm{S}$

Irrigation scheduling based on irrigation water to cumulative pan evaporation (IW/CPE) ratio of $0.4,0.8$ and 1.0 were applied in furrow in respective plots. Daily evaporation data was monitored from a standard US weather bureau Class A Pan evaporimeter installed inside the experimental site. The depth of irrigation water applied as $50 \mathrm{~mm}$.

A common light irrigation of $30 \mathrm{~mm}$ depth was applied to all plots just after planting for uniform seedling establishment. Irrigations were then given as per treatments when IW/CPE ratio reached the required value and the quantity of water applied was measured with the help of Parshall flume.

\section{Benefit-cost analysis}

The economic feasibility of different irrigation scheduling on three cultivars of tuberose was worked out through benefit: cost ratio analysis. Cost of cultivation including expenses incurred in land preparation, planting, intercultural operation, fertilizer application, plant protection measures, irrigation water and harvesting with labour charges was calculated as per prevailing market rates during the period of experimentation. Gross return was worked out using the prevailing market price of the flower produce. Net return was estimated by subtracting the cost of cultivation from the gross return value. Benefit: cost ratio was calculated by dividing net return with the cost of cultivation of individual treatment.

\section{Statistical analysis}

The spike and bulb yield data obtained from various irrigation schedules were subjected to analysis of variance techniques by using software packages of MS Excel and SPSS 12.0 version. Statistical significance between means of individual treatments was assessed using Fisher's Least Significant Difference (LSD) at 5\% probability level (Gomez and Gomez, 1984).

\section{Results and Discussion}

\section{Spike and bulb yields}

The spike and bulb yields of tuberose regardless of test varieties were significantly affected by various irrigation schedules (Table $3)$. The highest number of spike (270300/ha) and bulb yield (21.32 t/ha) were obtained with higher irrigation schedule at IW/CPE 1.0. This treatment was statistically at par with moderate deficit irrigation schedule at IW/CPE 0.8 recording the corresponding values of 268890/ha and 20.20 t/ha, respectively. Significantly the lowest spike and bulb yields (233037/ha and 17.97 t/ha, respectively) were found with lower deficit irrigation schedule at IW/CPE 0.4. The probable reason for obtaining higher yields with irrigation scheduling of IW/CPE 1.0 and 0.8 was due to higher water use by plants as stimulated by higher moisture distribution and storage in the soil profile and subsequent availability to plants (Tables 4 and 5, Fig. 1). On the contrary, water application at higher deficit irrigation schedule of IW/CPE 0.4 was not conducive for increasing plant yield due to variable moisture stress during the growth period. The results are almost in agreement with the findings of Rathore and Singh (2009) who noticed that increasing water application from 0.4 to $0.8 \mathrm{IW} / \mathrm{CPE}$ ratio improved the spike and bulb yield appreciably, however failed to increase yield beyond $0.8 \mathrm{IW} / \mathrm{CPE}$ 
ratios, thereby indicating water application at this level is not being utilized by crop. El Naggar and Byari (2009) also established that moisture stress condition as a result of inadequate or deficit water application in important phenological stages of tuberose plant adversely affected the growth, flowering and yield of flower due to reduction in the fertility of newly formed flowers (Slawinska et al., 2001). On the other hand, maintenance of optimum irrigation regime in soil might have built-up favourable moisture conditions resulting in better bulb development, bulblet multiplication, improved growth and yield of spikes due to improved water availability and absorption of plant nutrients (Deshmukh, 2012).

Among the varieties examined, irrespective of various irrigation schedules, the highest number of spike (265223/ha) and bulb production (20.98 t/ha) was detected in Calcutta double, which was at par with Calcutta single witnessing the corresponding yield values of 262033/ha and 20.10 t/ha, respectively. The performance of Prajwal variety in promoting spike and bulb yields was significantly inferior.

The interactions effects between the irrigation schedules and the tuberose varieties on spike and bulb production were significant. The highest number of spike (278160/ha) and bulb yield (22.47 t/ha) was achieved from Calcutta double imposed with irrigation scheduling of IW/CPE 1.0 and was statistically at par with irrigation schedule of IW/CPE 0.8 giving the spike number and bulb yield as $276330 /$ ha and $21.64 \mathrm{t} / \mathrm{ha}$, respectively.

The Calcutta single experienced with irrigation schedules of IW/CPE 1.0 and IW/CPE 0.8 did not vary significantly. Both were statistically competitive with the former two irrigation treatments for Calcutta double in terms of spike and bulb production. The minimum spike number and bulb yield were displayed by Prajwal at all irrigation schedules. The effect was more pronounced with higher level of deficit irrigation schedule than in moderate deficit irrigation schedule.

\section{Soil water balance and seasonal water use}

During the growing season of 2012-2013, contribution of effective rainfall utilizable for plant use (rainfall minus deep percolation) was $797.2 \mathrm{~mm}$, whereas the figures for soil profile moisture contribution at $0-30 \mathrm{~cm}$ rooting depth varied from 14.3 to $19.8 \mathrm{~mm}$. The amounts of irrigation water applied in treatments IW/CPE $0.4\left(\mathrm{I}_{1}\right), \mathrm{IW} / \mathrm{CPE} 0.8\left(\mathrm{I}_{2}\right)$ and IW/CPE $1.0\left(\mathrm{I}_{3}\right)$ were 272,544 and $680 \mathrm{~mm}$, respectively. Thus the seasonal water use by the plant was 1119.0, 1388.4 and $1512.5 \mathrm{~mm}$ for irrigation treatment of $\mathrm{I}_{1}, \mathrm{I}_{2}$, and $\mathrm{I}_{3}$, respectively (Table 4). It is conspicuous that contribution of soil profile moisture was relatively higher in deficit irrigation condition as compared with the full or optimum irrigation condition.

\section{Soil moisture distribution}

The distribution of soil moisture along the vertical distances just before and 48 hours after the irrigation under various irrigation treatments is furnished in Figure 1. A perusal of the results indicates that soil moisture contents decreased progressively with increasing soil depth at all irrigation level and the percentage variation was relatively more at higher irrigation level than in lower irrigation level. There was an increase in soil moisture storage in $0-15,15-30$ and $30-45 \mathrm{~cm}$ soil depth by $15.5,20.8$ and $26.8 \%$ for IW/CPE $0.4 ; 26.8$, 32.8 and $39.3 \%$ for IW/CPE 0.8 and $32.7,37.7$ and $45.1 \%$ for IW/CPE 1.0 , respectively over their respective status before irrigation (Table 5). This implies that there was sufficient soil moisture storage in the active crop root zone, relatively more so in higher irrigation schedule than in lower irrigation schedule. 
Table.1 Physical and hydro-physical properties of the experimental soil

\begin{tabular}{|c|c|c|c|c|c|c|c|c|}
\hline $\begin{array}{l}\text { Soil } \\
\text { depth } \\
(\mathrm{cm})\end{array}$ & $\begin{array}{l}\text { Sand } \\
(\%)\end{array}$ & $\begin{array}{l}\text { Silt } \\
(\%)\end{array}$ & $\begin{array}{l}\text { Clay } \\
(\%)\end{array}$ & Soil texture & $\begin{array}{l}\text { Bulk } \\
\text { density } \\
\left(\mathrm{g} / \mathrm{cm}^{3}\right)\end{array}$ & $\begin{array}{l}\text { Hydraulic } \\
\text { conductivity } \\
\text { (cm/hour) }\end{array}$ & $\begin{array}{c}\text { Field } \\
\text { capacity } \\
(w / w \%)\end{array}$ & $\begin{array}{l}\text { Permanent } \\
\text { wilting point } \\
\text { (w/w \%) }\end{array}$ \\
\hline $0-15$ & 70.2 & 14.4 & 15.5 & Sandy loam & 1.47 & 2.35 & 23.64 & 11.16 \\
\hline $15-30$ & 68.1 & 15.2 & 16.7 & Sandy loam & 1.51 & 2.23 & 21.38 & 10.74 \\
\hline $30-45$ & 78.92 & 12.27 & 8.81 & Sandy loam & 1.58 & 2.31 & 19.52 & 9.43 \\
\hline
\end{tabular}

Table.2 Chemical properties of the experimental soil

\begin{tabular}{|l|c|c|c|c|c|c|}
\hline $\begin{array}{l}\text { Soil depth } \\
(\mathbf{c m})\end{array}$ & $\begin{array}{c}\mathrm{pH} \\
(\mathbf{1}: \mathbf{2 . 5}\end{array}$ & $\begin{array}{c}\mathrm{EC} \\
(\mathbf{d S} / \mathbf{m})\end{array}$ & $\begin{array}{c}\text { Organic C } \\
(\%)\end{array}$ & $\begin{array}{c}\text { Available N } \\
(\mathbf{k g} / \mathbf{h a})\end{array}$ & $\begin{array}{c}\text { Available P } \\
(\mathbf{k g} / \mathbf{h a})\end{array}$ & $\begin{array}{c}\text { Available K } \\
\text { (kg/ha) }\end{array}$ \\
\hline $\mathbf{0 - 1 5}$ & 6.81 & 0.10 & 0.46 & 158.3 & 23.9 & 141.5 \\
\hline $\mathbf{1 5 - 3 0}$ & 6.38 & 0.08 & 0.41 & 140.5 & 21.6 & 127.3 \\
\hline $\mathbf{3 0 - 4 5}$ & 3.32 & 0.07 & 0.39 & 133.7 & 19.3 & 121.8 \\
\hline
\end{tabular}

Table.3 Effect of different irrigation schedules on spike and bulb yields of tuberose

\begin{tabular}{|c|c|c|c|c|c|c|c|c|}
\hline \multirow{3}{*}{$\begin{array}{l}\text { Irrigation } \\
\text { schedule }\end{array}$} & \multicolumn{4}{|c|}{ Spike yield (number/ha) } & \multicolumn{4}{|c|}{ Bulb yield (t/ha) } \\
\hline & \multicolumn{4}{|c|}{ Variety } & \multicolumn{4}{|c|}{ Variety } \\
\hline & $V_{1}$ & $\mathbf{V}_{2}$ & $\mathbf{V}_{3}$ & Mean & $V_{1}$ & $\mathbf{V}_{2}$ & $\mathbf{V}_{\mathbf{3}}$ & Mean \\
\hline$\overline{I_{1}}$ & 220000 & 237930 & 241180 & 233037 & 17.18 & 17.91 & 18.83 & 17.97 \\
\hline$I_{2}$ & 256670 & 273670 & 276330 & 268890 & 18.42 & 20.53 & 21.64 & 20.20 \\
\hline$I_{3}$ & 258240 & 274500 & 278160 & 270300 & 19.63 & 21.85 & 22.47 & 21.32 \\
\hline Mean & 244970 & 262033 & 265223 & - & 18.41 & 20.10 & 20.98 & - \\
\hline & I & V & I x V & & I & $\mathrm{V}$ & $\mathrm{I} \times \mathrm{V}$ & \\
\hline CD (5\%) & 3420 & 3420 & 6380 & & 1.21 & 1.21 & 2.17 & \\
\hline
\end{tabular}

$I_{I}=$ Irrigation at IW/CPE 0.4, $I_{2}=$ Irrigation at IW/CPE 0.8, $I_{3}=$ Irrigation at IW/CPE 1.0; $V_{1}=$ Prajwal, $V_{2}=$ Calcutta single, $V_{3}=$ Calcutta double

Table.4 Seasonal crop water use by tuberose plant at different irrigation schedules

\begin{tabular}{|l|c|c|c|c|c|}
\hline $\begin{array}{l}\text { Irrigation } \\
\text { schedule }\end{array}$ & $\begin{array}{c}\text { Profile contribution } \\
(\mathbf{m m})\end{array}$ & $\begin{array}{c}\text { Rainfall } \\
(\mathbf{m m})\end{array}$ & $\begin{array}{c}\text { Drainage } \\
(\mathbf{m m})\end{array}$ & $\begin{array}{c}\text { Irrigation } \\
\text { water }(\mathbf{m m})\end{array}$ & $\begin{array}{c}\text { ₹Total water use } \\
(\mathbf{m m})\end{array}$ \\
\hline $\mathrm{I}_{1}$ & 19.8 & 1319.0 & 521.8 & 272 & $\mathbf{1 1 1 9 . 0}$ \\
\hline $\mathrm{I}_{2}$ & 17.2 & 1319.0 & 521.8 & 544 & $\mathbf{1 3 8 8 . 4}$ \\
\hline $\mathrm{I}_{3}$ & 14.3 & 1319.0 & $\mathbf{5 2 1 . 8}$ & $\mathbf{6 8 0}$ & $\mathbf{1 5 1 2 . 5}$ \\
\hline
\end{tabular}

$I_{1}=$ Irrigation at IW/CPE 0.4, $I_{2}=$ Irrigation at IW/CPE 0.8, $I_{3}=$ Irrigation at IW/CPE 1.0, Depth of irrigation water@50 mm, =30 mm pre-planting irrigation water added for uniform seedlings establishment

Table.5 Soil moisture storage (\%) under different irrigation schedules in tuberose field

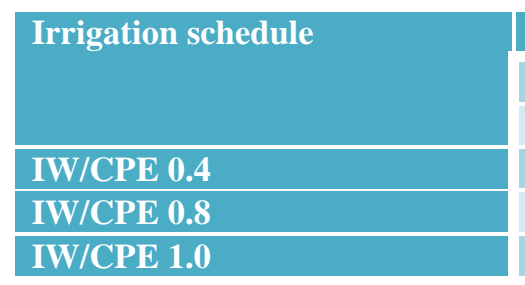

\begin{tabular}{|c|c|c|}
\hline \multicolumn{3}{|c|}{ Soil moisture storage (\%) } \\
\hline \multicolumn{3}{|c|}{ Soil depth $(\mathbf{c m})$} \\
\hline $\mathbf{0 - 1 5}$ & $\mathbf{1 5 - 3 0}$ & $\mathbf{3 0 - 4 5}$ \\
\hline 15.5 & 20.8 & 26.8 \\
\hline 26.8 & 32.8 & 39.3 \\
\hline 32.7 & 37.7 & 45.1 \\
\hline
\end{tabular}


Table.6 Economics of tuberose cultivation under different irrigation schedules

\begin{tabular}{|c|c|c|c|c|c|c|c|c|c|c|c|c|}
\hline \multirow[t]{2}{*}{ Particulars } & \multicolumn{3}{|c|}{ Prajwal } & \multicolumn{3}{|c|}{ Calcutta single } & \multicolumn{3}{|c|}{ Calcutta double } & \multicolumn{3}{|c|}{ Overall } \\
\hline & $\mathbf{I}_{1}$ & $\mathbf{I}_{2}$ & $\mathbf{I}_{3}$ & $\mathbf{I}_{1}$ & $\mathbf{I}_{2}$ & $\mathbf{I}_{3}$ & $\mathbf{I}_{1}$ & $\mathbf{I}_{2}$ & $\mathbf{I}_{3}$ & $\mathbf{I}_{1}$ & $\mathbf{I}_{2}$ & $\mathbf{I}_{3}$ \\
\hline $\begin{array}{l}\text { Cost of } \\
\text { cultivation } \\
\text { (Rs./ha) }\end{array}$ & 125000 & 135000 & 140000 & 125000 & 135000 & 140000 & 125000 & 135000 & 140000 & 125000 & 135000 & 140000 \\
\hline $\begin{array}{l}\text { Yield } \\
\text { (Spike no./ha) }\end{array}$ & 220000 & 256670 & 258240 & 237930 & 273670 & 274500 & 241180 & 276330 & 278960 & 233037 & 268890 & 270567 \\
\hline $\begin{array}{l}\text { Gross return } \\
\text { (Rs./ha) }\end{array}$ & 330000 & 385005 & 387360 & 356895 & 410505 & 411750 & 361770 & 414495 & 418440 & 349555 & 403335 & 405850 \\
\hline $\begin{array}{l}\text { Net return } \\
\text { (Rs./ha) }\end{array}$ & 205000 & 250005 & 247360 & 231895 & 275505 & 271750 & 236770 & 279495 & 278440 & 224555 & 268335 & 265850 \\
\hline $\begin{array}{l}\text { Benefit : cost } \\
\text { ratio }\end{array}$ & 1.64 & 1.85 & 1.77 & 1.86 & 2.04 & 1.94 & 1.89 & 2.07 & 1.99 & 1.80 & 1.99 & 1.90 \\
\hline
\end{tabular}


Fig.1 Soil moisture changes before (L) and after (R) irrigation under varied irrigation schedules

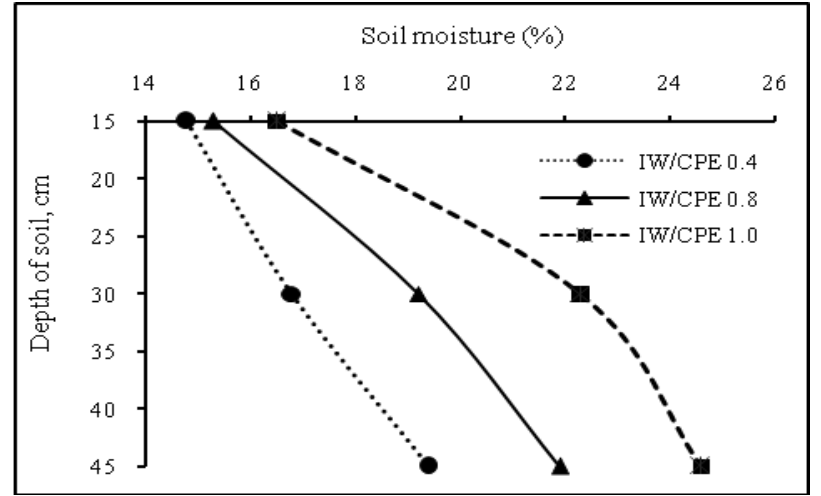

The lesser soil moisture content in surface layer than the layers underneath, irrespective of irrigation schedules, was ascribed to the more evaporation loss as well as higher moisture abstraction from surface layer as compared with the subsurface layers. At the end of the irrigation event, the same trend of distribution was observed at all irrigation levels. The magnitude was more discernible in irrigation schedule at IW/CPE 1.0 followed by IW/CPE 0.8. Comparatively low soil moisture contents before and after irrigation scheduling at IW/CPE 0.4 might be one of the contributing factor for the decline in spike and bulb yields as because the amount of water through IW/CPE 0.4 was not sufficient to meet the crop evapotranspiration demand and plants might experience variable soil moisture stress throughout the growth period.

\section{Economics}

The benefit-cost analysis was worked out to determine the economic feasibility of different irrigation schedule on tuberose cultivation (Table 6). The cost of production increased with increase in irrigation levels. The gross return and net return increased progressively due to increase in spike production under the influence of increasing levels of irrigation in sandy loam soil. The results showed that maximum gross return (Rs. 403335/ha), net return (Rs. 268335/ha) and benefit-cost ratio (1.99) was obtained from moderate deficit irrigation schedule of IW/CPE $0.8\left(\mathrm{I}_{2}\right)$.

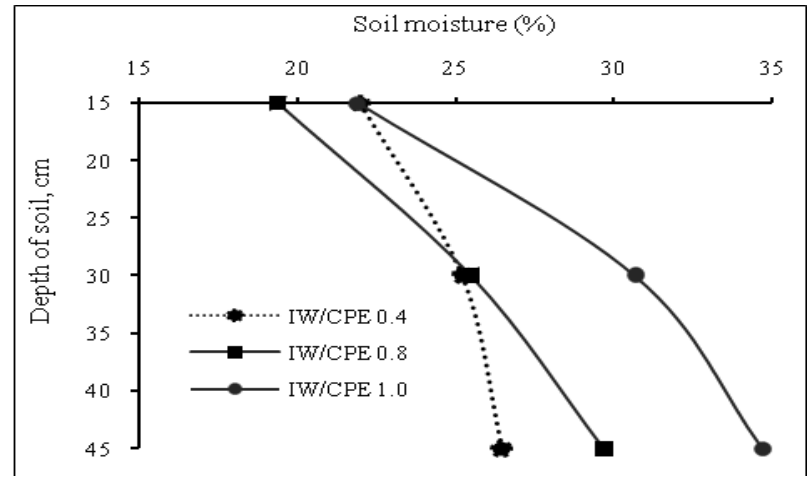

Highest economic benefit was also accomplished in irrigation schedule of IW/CPE 0.8 for Calcutta double followed by Calcutta single and Prajwal with the corresponding values of Rs. 414495/ha, Rs. 279495/ha and 2.07; Rs. 410505/ha, Rs. 275505/ha and 2.04; and Rs. 385005/ha, Rs. 247360/ha and 1.85, respectively. The economic benefit at higher irrigation schedule $\left(\mathrm{I}_{3}\right)$ was not optimistic as because the spike production, thus gross return did not increase proportionately with the increased irrigation level. Under limited water supply, imposing the plant with higher deficit irrigation schedule of IW/CPE $0.4 \quad\left(\mathrm{I}_{1}\right)$ especially for Calcutta double and Calcutta single could be a remunerative option in obtaining the benefit-cost ratio of 1.86 to 1.89 .

It may be concluded from the above study that tuberose grown in the Indo-Gangetic plains of West Bengal responded positively to varied levels of irrigation application. However, irrigation with higher moisture schedule at IW/CPE 1.0 showed maximum spike and bulb yields of plant and was being comparative with moderate deficit irrigation schedule of IW/CPE 0.8. Minimum yields were found in higher deficit irrigation schedule of IW/CPE 0.4. Calcutta double performed better followed by Calcutta single and Prajwal in promoting yields at all irrigation levels, the more so in higher irrigation regime than in lower irrigation regime. However, in consideration of moderate water use, relatively higher spike and bulb yields and maximum economic returns, deficit 
irrigation schedule at IW/CPE 0.8 for Calcutta double or Calcutta single cultivar may be advocated for tuberose growers in this region.

\section{References}

Alan, O., Gunen, Y, Ceylan, S. and Gunen, E. 2007. Effect of nitrogen applications on flower yield, some quality characteristics and leaf mineral content in tuberose (Polianthes tuberosa L.). Aegean Agric. Res. Ins. Direc., 17(1): 43-57.

Biswas, G.J., Kumar, P.N. and Bhattacharjee, A. 2006. Tuberose. Published by ICAR, New Delhi, Vol 1-2.

Deshmukh, M.R. 2012. Effect of various irrigation methods on growth, flowering and yield of tuberose (Polyanthes tuberosa L.). J. Hortl. Sci., 7(1): 94-97.

El Naggar, A.I. and Byari, S.H. 2009. Effects of Irrigation frequency regimes and weed control management on field grown tuberoses (Polianthes Tuberosa, L.) in the Saudi Arabian western region: 2. Bulb and bulblet's yield, growth and development and grade qualities. Egypt. J. Hort., 36(1): 119-147.

Gomez, K.A. and Gomez, A.A. 1983. Statistical Procedures for Agricultural Research. $2^{\text {nd }}$ Edn., Int. Rice Res. Inst., Los Banos, Philippines.

Halepyati, A.S., Sujatha, K. and Prabhakar, M.M. 1996. Growth, yield, water relations and its use in tuberose (Polianthes tuberose L.) as influenced by irrigation regime and nitrogen level. Ind. J. Agric. Sci., 65(12): 866-869.

Kabir, A.K.M.R., Iman, M.H., Mondal, M.M.A. and Chowdhury, S. 2011. Response of tuberose to integrated nutrient management. J. Environ. Sci. Natural Res., 4(2): 55-59.
Kour, R. and Sharma A. 2012. Growth and flowering as affected by NPK fertilizers in tuberose cv. single. The Asian J. Hort., 7 (2): 619-620.

Padaganur, V.G., Mokashi, A.N. and Patil, V.S. 2005. Flowering, flower quality and yield of tuberose as influenced by vermicompost, farmyard manure and cowdung. Karnataka J. Agric. Sci., 18: 729-734.

Panigrahi, P., Sahu, N. N. and Pradhan, S. 2011. Evaluating partial root-zone irrigation and mulching in okra (Abelmoschus esculentus L.) under a sub-humid tropical climate. J. Agric. Rural Dev. Tropics and Subtropics, 112(2): 169-175.

Patel, M.M., Parmar, P.B. and Parmar, B.R. 2006. Effect of nitrogen, phosphorus and spacing on growth and flowering in tuberose (Polianthes tuberosa L.) cv. Single. Indian J. Orn. Hort., 9(4): 286289.

Rathore, A.C. $\quad$ and Singh, J.N. 2009. Optimization of nitrogen application and irrigation for improved growth and spike production of tuberose (Polianthes tuberosa L.). Indian J. Soil Conser., 37(1): 45-49.

Simsek, M., Tonkaz, T., Kacira, M., Comiekcioglu, N., and Dogan, Z. 2005. The effects of different irrigation regimes on cucumber (Cucumbis salivus L.) yield and yield characteristics under open field conditions. Agric. Water Mng., 73: 173191.

Slawinska, J. and Obendorf, R.L. 2001 Buckwheat seed set in plant and during in vitro inflorescence culture: Evaluation of temperature and water deficient stress. Seed Sci. Res., 11: 223-233.

\section{How to cite this article:}

Banik, M., P. Ghatak, R. Ray and Patra, S.K. 2018. Yield, Water Use and Economics of Tuberose as Influenced by Different Irrigation Scheduling in Indo-Gangetic Plains. Int.J.Curr.Microbiol.App.Sci. 7(04): 922-930. doi: https://doi.org/10.20546/ijcmas.2018.704.098 